\title{
Medical Negligence Dispute Resolution in Malaysia: Time for legal reform
}

\author{
Izuan Izzaidi Azmi', Norfarhana Md Daud2, Prof. Bill Atkin³, Faznur Md Rashid Khan ${ }^{4}$ \\ 1 Faculty of Law, Universiti Teknologi MARA, Shah Alam, Selangor, Malaysia \\ 2 Ministry of Health, Malaysia \\ ${ }^{3}$ Faculty of Law, Victoria University of Wellington, New Zealand \\ ${ }^{4}$ Faznur Az-Zahrah \& Associates, Penang \\ izuan124@uitm.edu.my, farhanamddaud@gmail.com, bill.atkin@vuw.ac.nz, faznur@fza.com.my \\ Tel: 013-3736568
}

\begin{abstract}
As medical negligence has become a public concern today, there is an increasing number of medical negligence claims which commonly settled through litigation. However, numerous problems regarding the practice of litigation have been discovered. Hence, the research aims to examine the current medical dispute resolution in Malaysia to find a better solution for it. The findings show that there are weaknesses of the existing practice and found that mediation as an alternative dispute resolution is available and more suitable. Thus, the research provides the grounds for legal reform and recommendations for improvement of Malaysia's medical negligence dispute resolution framework.
\end{abstract}

Keywords: medical negligence; dispute resolutions; Malaysia

eISSN: 2398-4287@ 2021. The Authors. Published for AMER ABRA cE-Bs by e-International Publishing House, Ltd., UK. This is an open access article under the CC BYNC-ND license (http://creativecommons.org/licenses/by-nc-nd/4.0/). Peer-review under responsibility of AMER (Association of Malaysian Environment-Behaviour Researchers), ABRA (Association of Behavioural Researchers on Asians/Africans/Arabians) and CE-Bs (Centre for Environment-Behaviour Studies), Faculty of Architecture, Planning \& Surveying, Universiti Teknologi MARA, Malaysia.

DOl: https://doi.org/10.21834/ebpj.v6i16.2726

\subsection{Introduction}

Medical negligence is an issue that is frequently discussed by the public nowadays. One of the reasons is the fact that health is the most valuable asset of a person. Hence when negligence happens, it is taken seriously by the patient. However, not all mishaps can be compensated with money, for example, errors that resulted in death or disability. In most cases, victims seek explanations and apology from the health professional involved (Kassim et al., 2017).

Currently, the main avenue for medical negligence dispute resolution in Malaysia is litigation. The system is costly, time-consuming, and have many loopholes (Mokhtar, 2016). The litigation process also results in the court system's backlog, which hampers Malaysia's justice administration.

There are alternative dispute resolution mechanisms available for disputes resolution. Although not many are aware, both private mediation and court-annexed mediation are being practised in Malaysia. However, not much is known regarding the practice of mediation in medical negligence cases in the country.

\subsection{Purpose of the study}

eISSN: 2398-4287@ 2021. The Authors. Published for AMER ABRA cE-Bs by e-International Publishing House, Ltd., UK. This is an open access article under the CC BYNC-ND license (http://creativecommons.org/licenses/by-nc-nd/4.0). Peer-review under responsibility of AMER (Association of Malaysian Environment-Behaviour Researchers), ABRA (Association of Behavioural Researchers on Asians/Africans/Arabians) and cE-Bs (Centre for Environment-Behaviour Studies), Faculty of Architecture, Planning \& Surveying, Universiti Teknologi MARA, Malaysia.

DOI: https://doi.org/10.21834/ebpj.v6i16.2726 
This study explores the current regulatory framework of medical negligence dispute resolution in Malaysia and examines other available alternatives. The investigation is expected to assist in understanding the problems related to the litigation process in Malaysia.

\subsection{Objective of the study}

The study aims to identify the loopholes in Malaysia's current medical negligence dispute resolution framework, determine suitable alternatives for the dispute resolution process, and make recommendations for improving the framework.

\subsection{Literature Review}

According to Mokhtar (2016) and Islam (2019), medical negligence refers to doctors or medical practitioners' wrongdoings or misconduct. Consequently, patients and third party suffer injury or damage. To date, medical negligence claims are on the rise globally. Holden (2014) reported that legal claims and complaints received by the United Kingdom's General Dental Council (GDC) had risen year after year. In Malaysia, a similar situation is observed, although the statistic is not available (Hambali and Khodapanahandeh, 2014).

Currently, most people perceive litigation as the ultimate dispute resolution tool. Therefore, they often resort to litigation to settle their disputes (Mokhtar, 2016). Unfortunately, as medical negligence litigation is becoming more significant, numerous problems regarding the practice of litigation have come to light. The use of Tort's law in litigation means that the claimants shoulder the burden of proof to prove their case on a balance of probabilities (Mokhtar, 2016). In the litigation process, claimants must satisfy the substantive laws and overcome the difficulties in meeting the procedural law requirement. The requirement for expert witnesses and medical records also differentiates medical negligence claims from other personal injury claims (Kassim, 2008). The system is costly, lengthy, and challenging to prove the claims (Mokhtar,2016). Further, according to Kassim et al.(2017), litigation does not offer non-legal remedies such as explanation and apology.

According to Bielen et al. (2018), the high demand for litigation resulting in the court backlog. This issue was raised in Malaysia long ago when Kassim(2008) submitted that medical negligence claims significantly contribute to the court system's backlog, which causes a massive problem to Malaysia's justice administration. Malaysia undertakes diverse steps to reduce the number of backlogged cases, including the introduction of 'Fast Track' and 'Normal Track'. However, evidence shows that it is a long way to go before the number of cases can be reduced to a reasonable amount. In 2019, there were a total of 114,584 civil cases pending at court (Federal Court of Malaysia, 2020). Although it decreases in trend, the number was still relatively high.

Table 1: Statistic of the civil cases pending in court 2014-2019

\begin{tabular}{lrrrrrr}
\hline Court & \multicolumn{7}{c}{ Year } \\
& $\mathbf{2 0 1 4}$ & $\mathbf{2 0 1 5}$ & $\mathbf{2 0 1 6}$ & $\mathbf{2 0 1 7}$ & $\mathbf{2 0 1 8}^{*}$ & $\mathbf{2 0 1 9}$ \\
\hline Federal Court & 827 & 792 & 659 & 610 & - & 631 \\
Court of Appeal & 2,500 & 2,049 & 2,260 & 3,023 & - & 4,092 \\
High Court & 48,948 & 47,935 & 50,749 & 49,977 & - & 56,276 \\
Session Court & 16,286 & 16,782 & 14,869 & 13,602 & - & 16,021 \\
Magistrate Court & 58,632 & 59,427 & 53,488 & 48,822 & - & 37,564 \\
Total & 127,193 & 126,985 & 122,025 & 116,034 & - & 114,584 \\
\hline
\end{tabular}

*no data available

Therefore, several countries adopted different methods to address the problem. Among the mechanism is the no-fault system, which New Zealand had successfully implemented (Kasim and Najid, 2014). However, according to Kassim and Najid (2014), the no-fault system seems non-viable to be implemented for various reasons, such as the size of the population, no deterrence for future harm and the difficulty of funding the scheme.

Hambali and Khodapanahandeh (2014) and Mokhtar(2016) suggested that reform options, including ADR, should be looked into in resolving medical negligence claims. Some former and current members of the judiciary also had advocated mediation practice in the country, including the former Attorney General of Malaysia, Tan Sri Abdul Gani Patail, who acknowledged mediation as the best ADR form (Ishan Jan and Ali Mohamed, 2010). Apart from private mediation, the formalised form of mediation, namely court-annexed mediation, has been practised widely by the Malaysian court. Currently, Order 34 Rule 2(2)(a) of the Rules of Court 2012 (ROC 2012) provides that judges may encourage parties in disputes in a civil case to go through a mediation session in the pre-trial case management stage (Khan et al., 2020).

\subsection{Methodology}

A qualitative approach is adopted as it fits the need of this study. It allows and values in-depth explorations of the current medical negligence dispute resolution in Malaysia and its loopholes.

\subsection{Doctrinal study}


This study used doctrinal research to identify and determine the sources of law to analyse the legal doctrine and how it has been developed and applied (Singhal and Malik, 2012). References were made to journals, online journals, articles, and books to gain relevant, essential information and a deep understanding of the practice of medical dispute resolution in Malaysia. The study also utilised online databases such as Scopus, ProQuest, Lexis Nexis and the Current Law Journal (CLJ) using keywords 'medical negligence', 'Malaysia' and 'legal reform'.

\subsection{Data collection}

According to Given (2008), in qualitative research, the data collection always involves face-to-face interaction with the study participants through observation and interviews. For the purpose of this study, the researcher collected data through semi-structured interviews. The method is flexible enough to allow the researcher to explore the issue and structured enough to help generate data from the respondents. The researcher interviewed selected respondents from various backgrounds related to the medical negligence area, i.e., the Malaysian Dental Council, Malaysian Dental Association, Attorney General's Chamber and Faculty of Law, Universiti Teknologi MARA, Shah Alam.

\subsection{Data Analysis}

The manipulation and coding of qualitative data were done by transferring interviews from oral to written form and later coded for analysis to identify the topics, issues, points of similarity and differences. Then, the researcher did a thematic analysis by bringing together the codes of the transcripts.

\subsection{Findings}

\subsection{Problems related to medical negligence dispute resolution in Malaysia}

\subsubsection{Socio-economic problems}

Medical negligence cases require a lengthy trial to settle. Medical negligence claims have to satisfy both substantive laws and procedural requirements and often have to face evidential difficulties, resulting in a delay in case disposal. In Foo Fio Na v Hospital Assunta \& Anor, it took twenty-four years to conclude (Mokhtar, 2016).

Another factor contributing to the delay is the shortage of judges and judicial commissioners, and the limited number of cases the court can hear per month (Ishan Jan and Ali Mohamed, 2010). Hamid Sultan bin Abu Backer JC in Pembinaan Majujaya \& 2 Ors v Lau Tiong IK Construction stated that there is disproportionality between the cases and the human resources. Ishan Jan and Ali Mohamed (2010) also profoundly believed that the failure to observe the schedule or the hearing dates and the unnecessary request for adjournment or postponement of cases contribute to the delay in delivering justice.

Besides, another problem with medical negligence litigation is they are expensive (Mokhtar, 2016). The high cost is due to the long period consumed to complete a litigation process, as evidential difficulties always occur. Moreover, medical malpractice cases are among the most challenging to try and take longer than other personal injury cases because of the complexity of the expert medical testimony (Kassim, 2008). The parties have to incur a substantial pay-out to the legal representatives. Further, hiring an attorney demands a vast sum of money. Other payments may include court costs, settlements and other expenses that are needed to solve the problem.

\subsubsection{Non-legal remedies are not offered}

Victims in medical negligence cases do not only seek compensation through litigation (Kassim et al., 2017). Sometimes, what matters the most is that they want to know the truth behind the incident and the assurance that the incident will not recur. They require explanations, information and a sincere apology from the defendant. However, the current litigation system does not offer these nonlegal remedies (Hambali and Khodapanahandeh, 2014).

Apology serves as a remedial behaviour, which reduces the negative consequence of the negligence, thus, restoring the defendant's reputation (Kassim et al., 2017). An apology has a significant and healing effect on the dispute. It also shows that the defendant acknowledges his responsibility. As a consequence, it may lessen the anger of the victim.

\subsubsection{Problems specific to medical negligence cases}

Firstly, the unreliability of expert witness causes problems in medical dispute resolution. To prove the existence of the duty of care and the breach of the duty of care in a medical negligence claim needs an expert witness to give testimony. However, there is difficulty in obtaining expert evidence (Hambali and Khodapanahandeh,2014). According to Hambali \& Khodapanahandeh (2014), the 'conspiracy of silence', where the doctors are hesitant to testify against each other, contributed to the difficulty. Doctors feel that they should protect each other, and to some, it is troublesome to attend court and be examined during the trial.

Secondly, a complaint filed against a doctor may tarnish his reputation and credibility. The case will be reported and may cause the public to look down on them. As a result, the doctor may lose his self-esteem and persuade him to avoid risky medical procedure and practice defensive medicine (Hambali \& Khodapanahandeh, 2014).

Thirdly, there is a relation between the medical insurance premium rates and the number of claims and compensation awarded. Born et al. (2019) submitted that the burden of medical malpractice risk might impact malpractice insurance costs and availability. The rise in medical negligence claims and a high amount of compensation will increase premium rates (Hambali \& Khodapanahandeh, 
2014). Currently, an increasing amount of compensation is evident. For example, the compensation amounting RM2,000,000.00 awarded in an O\&G and Paeds Neuro case in 2008, while in another O\&G and Paeds Neuro case in 2018, the amount of compensation was RM5,000,000.00 (Bastiampillai et al., 2018).

\subsubsection{Legal problems}

\subsubsection{Limitation period}

The Malaysia Limitation Act provided that a person has six years from the date on which the cause of action is accrued. A medical negligence claim has to be initiated and brought to court within a time-frame called the limitation period (Mokhtar, 2016). If the period has elapsed without an action being instituted, the injured party would no longer be allowed to bring the matter to court (Okanga, 2019). The limitation period has two importance; to protect the defendants from stale claims, avoid delay from the plaintiffs' part, and ensure a finality for both parties.

However, the limitation period imposes difficulties in medical negligence cases because the damage or injury may occur at a different time from the date of the cause of action (Kassim, 2008). For example, in case of an adverse effect of medication, it may take years after the drugs' ingestion for damage to appear. In this case, the damage may occur after the expiration of the limitation period. This factor is different in other personal injury claims, such as an accident, where the injury and the cause of injury happen simultaneously. According to Hambali and Khodapanahandeh (2014), as there is no provision on latent injury under the Malaysia Limitation Act 1953, it is difficult to deal with latent injury caused by medical negligence.

\subsubsection{No specific legislation on medical negligence}

At the moment, medical negligence is not being in the purview of any provisions in the country (Islam, 2019). The inexistence of specific legislation regarding medical negligence results in difficulties for the court to decide on the case and difficulties on the plaintiff and the defendant.

Furthermore, as Mokhtar (2016) stated, claimants shall also address the Evidence Act 1950 and Tort's law in a well-defined manner for substantive purposes. For procedural law, they have to comply with the Rules of Court 2012. Islam (2019) noted that Tort only provides compensation, and the decision by the court is based on the evidence and the law.

\subsection{Analysis of the 'No-Fault' System in New Zealand}

In 1974, New Zealand implemented the no-fault system (Kassim and Najid, 2013). The idea originated from the Woodhouse Report's recommendation and is administered by the Accident Compensation Commission (ACC). The Accident Compensation Scheme by ACC insured against all personal injuries, unless the injuries are not covered under the scheme, such as 'informed consent' cases.

However, Kassim and Najid (2013) submitted that more thorough research needs to be done if a 'no-fault' scheme to be implemented in Malaysia as there are differences between Malaysia and New Zealand regarding the population size, social standing, political ideology and financial commitment.

It is also essential to address the issue of funding the scheme. With a 'no-fault' system, government engagement is needed as it is a publicly funded scheme (Kassim, 2008). In New Zealand, the funding is performed by levies and general revenues. If it means that the tax will increase to allow a 'no-fault' scheme to be administered, an objection from the public is inevitable, as Kassim and Najid (2013) explained. On the other hand, Holden (2014) raised the issue of the escalating number of patients claiming compensation with the scheme.

Other disadvantages of a 'no-fault' as described by Kassim and Najid (2013) include:

1. Rigid eligibility criteria.

2. Low levels of compensation.

3. Accountability issues.

4. No guarantee of non-legal remedies.

5. Lack of incentives to avoid unsafe practice and no access to justice.

\subsection{Alternative Dispute Resolutions (ADR) - Mediation as Alternative Solution}

ADR methods are dispute resolution mechanisms that include negotiation, mediation, conciliation and arbitration. Negotiation is the most basic ADR form, where there is no third-party involvement (Ishan Jan and Ali Mohamed, 2010). On the other hand, there are third parties' involvement in mediation and conciliation, but the role is different. A third party in conciliation plays a more interventionist role than mediation, whereby in mediation, the third party is neutral, and the function is merely to facilitate the discussion. Meanwhile, the arbitration process is the more formal form of ADR.

Among the various ADR methods, mediation is the most effective and reliable for medical dispute resolution as suggested by Mokhtar (2016) and Khodapanahandeh and Hambali (2014). In mediation, parties' consent is reached, whereas arbitration involves a more formal and complicated process, almost like mini-trials, and the decision is by the arbitrator and is binding (Ishan Jan and Ali Mohamed, 2010). Furthermore, according to Khodapanahandeh and Hambali (2014), arbitration is inflexible and adversarial compared to mediation resulting in a less satisfying and less efficient process. With lawyers present in arbitration, the process is harsher and costly. The situation is different from mediation, where the mediator will ensure a friendly environment and facilitate the parties to achieve amicable settlements. Khodapanahandeh and Siti Naaishah (2014) cited Jacqueline R (1983), who argued that arbitration is more proper in settling commercial issues such as building contracts, insurance and patents. 
In general, Shipley (2018) defined mediation as a form of a facilitated discussion by a neutral third party, done out of the court. Claassen (2016) submitted that mediation has a high success rate, estimated between $80-90 \%$. Some countries have already practised mediation as an alternative in civil cases. In Hong Kong, legal practitioners need to advise their clients on mediation benefits before resorting to court litigation. Failure to do so may cause them to be barred from practising. Meanwhile, in Britain, it was decided in Halsey v. Milton Keynes NHS Trust [2004] EWCA Civ 576 that "all members who conduct litigation should now routinely consider with their clients whether their disputes are suitable for ADR".

Shipley (2018) stated that mediation has many benefits, including less costly compared to court litigation, less time consuming, allows open and productive discussion between the parties, and provides opportunities for the medical practitioner to learn from his mistakes and improve himself. It is a notable fact that court litigation is high in cost based on numerous studies. According to Shipley (2018), litigation costs are sometimes much higher than the compensation value; that is to say, it is worth the effort and money spent.

ADR process does not rely on substantive law. Mokhtar (2016) stated that the burden of proof that is complicated and challenging in the adversarial system needs not to be proved in a mediation process. In mediation, both parties are empowered to achieve mutual understanding, contrary to the fault system where judges determine the question of law. Mokhtar (2016) also highlighted that mediation would also preserve the doctor-patient relationship. Furthermore, in litigation, the objective is monetary compensation, but not the dispute's personal issue. Chandra and Math (2016) found that various remedies can be achieved through mediation due to its flexibility, such as an admission of negligence by the doctor or a training program to the medical practitioner to prevent future fault that can lead to other negligent.

According to Khan, Bastiampillai and Mon (2020), Order 34 Rule 2(2)(a) of Malaysia's Rules of Court 2012 (ROC 2012) provides that judges may encourage parties in disputes in a civil case to go through a mediation session in the pre-trial case management stage. This is further explained in Practice Direction No.4 of 2016 (Practice Direction on Mediation) effective on 15 July 2016. However, it is not specific for medical negligence cases, and there is also no pre-action protocol to explain steps that the parties must take in medical dispute cases (Practice Direction No.4, 2016).

\subsection{Analysis \& Discussions}

Based on the library-based research and interviews conducted, there are many medical negligence cases in Malaysia. Although the exact number and statistics on the issue are non-existent due to the non-systematic collection of the data, it can be supported by the reported cases by the bodies involved in medical negligence cases. As the public today is more aware of their rights, they tend to take action for medical negligence against private and public healthcare facilities, which has contributed to the increased in the number of cases.

Despite the fact that most medical negligence cases in Malaysia were solved through litigation, the study found that it is not the optimum approach for it. This is due to the fact that the Tort system provides for compensation only when the doctor or any other medical personnel assisting in treating the patient is proven to be negligent. However, establishing a doctor or health professional's negligence is an intricate matter to adjudicate because of its complex and protracted process.

Further, all respondents also agreed that the trial process takes a long and arduous time. It may cost the claimants or plaintiffs a hard time before getting their cases settled. The court process is quite lengthy too. The burden of proving medical negligence cases requires extra knowledge as medical law itself is a unique field in the legal industry.

Based on the findings, it is safe to say that medical negligence dispute resolution in Malaysia needs to be improved. By far, the study found that mediation is the best alternative to litigation in settling medical negligence dispute in Malaysia. However, work to improve the current framework on the practice of mediation is needed as it is too general and not specific to medical negligence cases.

\subsection{Conclusion}

In conclusion, as litigation demonstrates many weaknesses despite the rising number of medical negligence cases, it is high time for Malaysia to consider a legal reform for medical negligence dispute resolution. It is essential to find an alternative to litigation that is more effective in terms of cost, time and money, and can satisfy parties in disputes. The findings supported the view that mediation may be a better solution. Besides avoiding the demerits of litigation, mediation has been proven to have many advantages. Therefore, further research is suggested to examine mediation as an alternative solution in medical negligence dispute resolution and analyse the current practice of mediation in medical negligence cases in Malaysia for improvement.

\section{Acknowledgement}

The authors thank all respondents from the Malaysian Dental Council, Malaysian Dental Association, Attorney General's Chamber and UiTM for their contribution.

\section{Paper Contribution to Related Field of Study}

The authors hope that the study will help policymakers formulate a legal reform for medical negligence dispute resolution in Malaysia. 


\section{References}

Bastiampillai, A., Hamid, M. I. B. A., \& Abd, N. A. B. (2018). The Implementation Of Mediation In Medical Negligence Disputes In Malaysia. Proceedings-ICLG 2018, 246.

Bielen, S., Peeters, L., Marneffe, W., \& Vereeck, L. (2018). Backlogs and litigation rates: Testing congestion equilibrium across European judiciaries. International Review of Law and Economics, 53, 9-22.

Born, P. H., Karl, J. B., \& Montesinos-Yufa, H. (2019). The effect of damage cap reforms on medical malpractice insurance market conditions during periods of crises. Journal of Risk and Insurance, 86(4), 1045-1071.

Chandra, M. S., \& Math, S. B. (2016). Progress in Medicine: Compensation and medical negligence in India: Does the system need a quick fix or an overhaul?. Annals of Indian Academy of Neurology, 19(Suppl 1), S21.

Claassen, N. (2016). Mediation as an alternative solution to medical malpractice court claims. South African Journal of Bioethics and Law, 9(1), 7.

Federal Court of Malaysia (2020). <http://www.kehakiman.gov.my/en/statistics> accessed on 3 November 2020.

Given, L. M. (Ed.). (2008). The Sage encyclopedia of qualitative research methods. Sage publications.

Halsey v. Milton Keynes NHS Trust [2004] EWCA Civ 576

Hambali, S. N., \& Khodapanahandeh, S. (2014). Review of medical malpractice issues in Malaysia under tort litigation system. Global journal of health science, 6(4), 76. Holden, A. C. L. (2014). The ExTORTion of dentistry-is litigation and over-regulation best for our patients?. British dental journal, 217(6), 269-270.

Islam, M. Z. (2019). Medical negligence: Current position of Malaysia and Bangladesh. World, 8(3), 18-21.

Ishan Jan, Mohammad Naqib and Ali Mohamed, Ashgar Ali (2010) Mediation in Malaysia: the law and practice. LexisNexis Malaysia Sdn Bhd, Selangor, Malaysia. ISBN 9789675371844

Jacqueline R. Bau, (1983). Medical Malpractice Arbitration: A Patient's Perspective. Washington University Law Review, 61(1)

Khan, H. A., Bastiampillai, A., \& Mon, S. W.(2020). Mediation as a Suitable Dispute Resolution Method in Medical Negligence Cases: Special Reference to the Malaysian Position. Pertanika J. Soc. Sci. \& Hum.28(3)

Khodapanahandeh, S., \& Hambali, S. N. (2014). Efficiency of Using "Alternative Dispute Resolution" Method in Medical Negligence. Advances in Natural and Applied Sciences, 8(13), 1-5.

Mokhtar, M. F. M. (2016). Medical Negligence Dispute in Malaysia: Choosing Mediation as the Best Constructive Approach to Address the Paradoxes in Medical Negligence Claims. European Journal of Interdisciplinary Studies, 2(2), 202-211.

Okanga, O. (2019). Legal Uncertainty and Conflict of Laws in the Application of Statutes of Limitation in Nigeria. Available at SSRN 3401069.

Pembinaan Majujaya \& 2 Ors v Lau Tiong IK Construction Sdn Bhd(unreported, 23 January 2008; Civil Appeal No 12-5-2005), [2008] MLJU 17

Practice Direction No.4, 2016

Kassim,P.N.J. (2008). Medical Negligence Law in Malaysia (Revised edn 2008)International Law Book Services

Kassim, P. N. J., Mohammad, D., \& Saleh, M. R. (2017). MEDICAL APOLOGY'AT CROSSROADS: AN EFFECTIVE DISPUTE RESOLUTION MECHANISM VERSUS ADMISSION OF LIABILITY. Copyright@ 2017 Ahmad Ibrahim Kulliyyah of Laws International Islamic University Malaysia Kuala Lumpur, 43(4), 170.

Kassim, P. N. J., \& Najid, K. M. (2013, January). Medical negligence disputes in Malaysia: resolving through hazards of litigation or through community responsibilities?. In Proceedings of World Academy of Science, Engineering and Technology (No. 78, p. 1607). World Academy of Science, Engineering and Technology (WASET).

Shipley, A. (2018). Mediation In Medical Malpractice Cases: An Opportunity For Financial Savings, Emotional Closure, And Future Medical Improvement. Dispute Resolution Journal, 73(2), 39-49.

Singhal, A. K., \& Malik, I. (2012). Doctrinal and socio-legal methods of research: merits and demerits. Educational Research Journal, 2(7), 252-256. 